democratic deficits and how it entrenches privileges only available to the powerful in society. The independent expert on the promotion of a democratic and equitable international order has denounced how ISDS is an affront to democracy and the rule of law. For many years, nongovernmental organizations have voiced concerns regarding the loss of regulatory space for the protection of human rights and the environment. Or, in other words, how ISDS is posing an obstacle to sustainable development, at a time when the global scientific consensus is calling for urgent measures to safeguard planetary boundaries in the face of destructive investments.

ISDS is not just inadequate, however; investigative journalists have exposed how criminals resort to ISDS to avoid prosecution. For example, their reports show how corrupt businesses use ISDS to avoid investigations in Egypt and elsewhere. Nongovernmental organizations similarly have decried how ISDS has been abused by corporations to blackmail governments to adopt policies in their favor, such as in the case of Pacific Rim versus El Salvador mentioned above. In that case, when the government did not provide the company with mining permits - to which it had no right under internal law - and when the government did not change the mining law to favor the company, the investor initiated ISDS claims.

Addressing asymmetries in the mechanisms for accountability should also confront impunity where investors harm the rights of communities. Confronting impunity may require reforming the Rome Statute of the International Criminal Court, so that when the Office of the Prosecutor receives a complaint from indigenous communities decimated by the systematic and widespread destruction of the Amazon rainforest perpetrated by an oil company, it may have the authority to investigate. Legal changes due include establishing criminal responsibility of corporations and clarifying the environmental dimensions of crimes against humanity.

Confronting impunity was also an important driver for the UN Guiding Principles on Business and Human Rights, adopted by the Human Rights Council in 2011. But their voluntary character also evidences their limitations. States such as France are beginning to adopt internal legislation for mandatory due diligence, including in respect to extraterritorial elements of supply chains. The efforts to establish legal standards for corporate accountability resonated also at the council in 2014 , when it decided to negotiate a treaty on transnational corporations and human rights. That discussion is in its early stages, and it has already identified key elements of the debate, including international duties of businesses, mechanisms for international cooperation, and effective remedies for victims. While it is still early to gauge progress, the initiative is in itself an expression of renewed efforts at addressing asymmetries in the mechanisms for accountability.

\title{
Heading Off Disputes by Paying Attention to Human Rights in Foreign Investor/Host State Contract Negotiations
}

doi:10.1017/amp.2017.61

\section{By John F. Sherman III*}

Other panelists have talked about the increasing relevance of human rights to bilateral treaty arbitrations between governments and foreign investors. This is a very important development.

\footnotetext{
* General Counsel, Shift New York. Shift, Who We Are, at https://www.shiftproject.org/who-we-are/team/john-f.-sherman-iii/. My remarks draw heavily from Professor John Ruggie's Keynote Remarks at the Association of International Petroleum Negotiators in Washington, D.C. (April 20, 2012), at https://business-humanrights.org/sites/default/files/ media/documents/ruggie/ruggie-remarks-association-intl-petroleum-negotiators-20-apr-2012.pdf [hereinafter Ruggie]. I also wish to thank Andrea Saldarriaga of the London School of Economics for her advice.
} 
However, my focus is on how to prevent the disputes that give rise to those arbitrations in the first place. If human rights are not addressed up front, in host state/foreign investor contract negotiations, they will come back to bite people, states, and investors. To do so, I want to talk about the 2011 UN Guiding Principles on Business and Human Rights, and their addendum, the Principles for Responsible Contracts.

Following six years of research, pilot projects, and over fifty multistakeholder consultations, the UN Guiding Principles on Business and Human Rights (Guiding Principles) were unanimously endorsed by the UN Human Rights Council in 2011. ${ }^{1}$ They have since become the authoritative global standard for business and human rights. They provide a blueprint for how states can protect human rights and how businesses can respect them. ${ }^{2}$ And they are increasingly reflected or incorporated in law and public policy, the policies and practices of leading companies, multistakeholder norms, financial and commercial transactions, judicial and nonjudicial dispute processes, and the advocacy of civil society. ${ }^{3}$ As other panelists have pointed out, they have begun to make their way into bilateral treaty arbitration decisions. ${ }^{4}$

During his mandate, Professor John Ruggie, the special representative of the UN SecretaryGeneral on business and human rights, and author of the Guiding Principles, focused on these contracts, because some of the greatest human rights challenges exist in major infrastructure projects funded by foreign investment in countries with weak governance. A downward spiral in trust between foreign investors and communities can result in the loss of a company's social license to operate long before it loses its legal license to operate.

Major infrastructure projects can have positive and negative impacts on human rights. The positive impacts can include job growth, tax revenue, and development of needed infrastructure. The negative impacts can include the forced resettlement of communities without compensation, soil, water, and air pollution, and charges of forced labor, rape, and extrajudicial killings by security forces protecting company assets. The worst problems take place in countries with weak governance and conflict zones. ${ }^{5}$

In addition, community conflict is costly to businesses. Litigation is often the least of a company's concerns. The most frequent cost of company/community conflict is lost productivity due to delay. A 2008 Goldman Sachs study of 190 oil and gas projects showed that the time to come on line had doubled over last decade. The delays were attributed to technical and political complexity; with stakeholder risk - notably including community conflict — constituting the largest category of nontechnical risk. One company estimated that it had incurred US $\$ 6.5$ billion of delay costs in two years. Extractive company losses are similar: based on studies in Peru, it has been estimated that a $\$ 3$ to $\$ 5$ billion mining project will suffer $\$ 2$ million per day of delay costs from community conflict. The most overlooked cost is management distraction, sometimes as high as 50 percent. And the greatest cost is lost opportunities. ${ }^{6}$

\footnotetext{
${ }^{1}$ United Nations Human Rights Office of the High Commissioner, Guiding Principles on Business and Human Rights (2011), at http://www.ohchr.org/Documents/Publications/GuidingPrinciplesBusinessHR_EN.pdf.

${ }^{2}$ Zeid Ra'ad Al Hussein, Ethical Pursuit of Prosperity, The LAw Society GAZETTE (Mar. 23, 2015), available at http:/ www.lawgazette.co.uk/analysis/comment-and-opinion/ethical-pursuit-of-prosperity/5047796.fullarticle.

${ }^{3}$ Reference Annex to the IBA Practical Guide on Business and Human Rights for Business Lawyers Section 2.1.2 (2016), available at http://www.ibanet.org/LPRU/Business-and-Human-Rights-Documents.aspx [hereinafter IBA].

${ }^{4}$ E.g., Ubaser S.A. et al. and The Argentine Republic, ICSID Case No. ARB/07/26 (2016), available at https://www.italaw.com/sites/default/files/case-documents/italaw8136_1.pdf.

${ }^{5}$ Ruggie, supra note *.

${ }^{6}$ Rachel Davis \& Daniel Franks, Costs of Company-Community Conflict in the Extractive Sector (2014), available at http://shiftproject.org/sites/default/files/Costs\%20of\%20Conflict_Davis\%20\&\%20Franks.pdf.
} 
The Guiding Principles are founded on three interdependent pillars: Pillar I is the state duty to protect human rights that businesses may affect. It is based on their obligations under international treaties, and it is addressed by policy making, legislation, investigation, and adjudication. Pillar II is the business responsibility to protect human rights. It is a road map for companies to know and show that they are protecting human rights. It expects that companies will embed respect for human rights in their organization and culture from the top down, use human rights due diligence to identify and manage their human rights risks, and remedy human rights harm that they have caused or contributed to. Pillar III is the need for greater access to remedy by victims of human rights abuses, both judicial and nonjudicial.

The Principles for Responsible Contracts (Contract Principles) are an addendum to the Guiding Principles. ${ }^{7}$ Viewed through the lens of the Guiding Principles, host state/foreign investor agreements sit at the crossroads of the state duty to protect human rights from business-related harm and the business responsibility to respect human rights. Their negotiation offers a critical opportunity to get things right at the outset.

The Contract Principles provide guidance for addressing human rights risks in the negotiation of host state/foreign investor contract negotiations. Their approach is to identify the issues that negotiators should consider. They contain a list of ten principles and recommendations. They don't provide boilerplate language for lawyers to cut and paste.

Three critical principles relate to risk identification, stabilization clauses, and physical security. The risk identification principle recommends that the parties identify human rights risks that the project may pose at the outset, by asking what is the foreseeable harm, whether the parties have the capacity to address them, whether there is quality information about the harm, and where the funding will come from.

The stabilization clause principle recognizes that the stability of a long-term investment project is important for all parties, but cautions that they should allow the state to exercise its duty to protect human rights. They should not be used to tie the state's hands when it acts on bona fide public interest grounds and in a nondiscriminatory fashion.

Finally, the physical security principle recognizes that the parties need to focus attention on negotiating public and private security arrangements, since this is often a potential source of the most severe human rights harm. As a result, it is recommended that the parties agree upon protocols to manage security through project life, including how local law enforcement should be involved, how private and public security should coordinate, and whether they are in line with international and humanitarian security standards. It is also recommended that the parties agree upon operational level grievance mechanisms and community engagement regarding security.

To conclude, host state/foreign investment contracts are at the ground floor of what may become a bilateral investment treaty arbitration. Heading off the human rights concerns at that level through negotiation will greatly serve the interests of all stakeholders.

\footnotetext{
${ }^{7}$ United Nations Human Rights Office of the High Commissioner, Principles for Responsible Contracts: Integrating the Management of Human Rights Risks into State-Investor Contract Negotations (2015), at http://www.ohchr.org/Documents/ Publications/Principles_ResponsibleContracts_HR_PUB_15_1_EN.pdf.
} 